\title{
Immunoadsorbent plasmapheresis for a patient with antiphospholipid syndrome during pregnancy
}

\author{
S Kobayashi, N Tamura, H Tsuda, C Mokuno, H Hashimoto, S Hirose
}

\begin{abstract}
The case of a 34 year old woman with systemic lupus erythematosus with a history of three previous recurrent abortions and lupus anticoagulant and anticardiolipin antibodies is reported. Immunoadsorbent plasmapheresis with a dextran sulphate column was used to remove lupus anticoagulant, anticardiolipin antibodies, and antibodies to DNA during her fourth pregnancy in combination with low doses of aspirin and prednisolone. Although during the course of treatment prednisolone was transiently increased to $\mathbf{3 0}$ $\mathrm{mg} / \mathrm{day}$ owing to an asymptomatic increase of lupus anticoagulant and anticardiolipin antibodies, the levels of lupus anticoagulant, anticardiolipin antibodies, and antibodies to DNA were decreased by immunoadsorbent plasmapheresis and a baby girl was delivered successfully by caesarean section. Therefore, immunoadsorbent plasmapheresis with dextran sulphate seems to reduce the risk of recurrent abortion in patients with the antiphospholipid syndrome.
\end{abstract}

Lupus anticoagulant and anticardiolipin antibodies are high risk factors for repeated abortion and intrauterine death. ${ }^{1-3}$ These factors have been associated with arterial or venous thrombosis, or both. Lupus anticoagulant interferes at the level of the prothrombin activation complex of the clotting cascade ${ }^{4}$ and may interfere with the production of prostacyclin by the vessel wall and other tissues, including the myometrium, during pregnancy. ${ }^{5}$

It was noted that treatment with high dose prednisolone $(40-60 \mathrm{mg} /$ day) in combination with aspirin $(75 \mathrm{mg} /$ day $)$ improved fetal survival in pregnant women with lupus anticoagulant and poor obstetric history. ${ }^{16}$ Such treatment for several months sometimes causes serious maternal adverse reactions, however, and the effect of high dose prednisolone on the fetus is unknown. In addition, therapeutic benefits are not always obtained and, therefore, alternative treatments should be evaluated.

Recently, treatment with immunoadsorbent plasmapheresis using a dextran sulphate column was introduced for patients with systemic lupus erythematosus to remove antibodies to DNA, ${ }^{7}$ and we found that anticardiolipin antibodies and lupus anticoagulant bind with dextran sulphate by anionic charge. ${ }^{8}$ Here, we would like to report the case of a patient with systemic Iupus erythematosus with lupus anticoagulant, anticardiolipin antibodies, and recurrent spontaneous abortion who was treated with the new approach of immunoadsorbent plasmapheresis during pregnancy.

Materials and methods

PLASMA SEPARATOR AND ADSORBENT COLUMN As a plasma separator, hollow fibre membrane filters of polysulphone with an average pore size of $0.2 \mu \mathrm{m}$ and effective surface area of $0.5 \mathrm{~m}^{2}$ (SF 05; Kanegafuchi Chemical Industry, Tokyo, Japan), were used together with Liposorber LA 40 (Kanegafuchi Chemical Industry), in which dextran sulphate cellulose beads $(350 \mathrm{ml})$ were packed and used as the sorbent gel for lupus anticoagulant, anticardiolipin antibodies, and antibodies to DNA.

\section{PROCEDURE FOR PLASMAPHERESIS}

Blood was withdrawn at a rate of $50 \mathrm{ml} / \mathrm{min}$ by a peristaltic pump through a double lumen catheter inserted into the femoral vein. Plasma was separated at a speed of $20 \mathrm{ml} / \mathrm{min}$ and passed through the Liposorber in a downward flow. The filtrate was infused into the patient with the portion rich in blood cells. The total extracorporeal circulation volume was about $400 \mathrm{ml}$. For anticoagulant, nafamostat mesilate ${ }^{9}$ (FUT-175; Torii Co, Tokyo, Japan) was used at an initial dose of $20 \mathrm{mg}$ and then continuously infused at a rate of $20 \mathrm{mg} / \mathrm{h}$. In this patient one litre of plasma was treated for each procedure. This procedure was carried out two to three times a week. Nafamostat mesilate, with a half life of eight minutes, prolongs activated partial thromboplastin time (APTT), and therefore APTT, anticardiolipin antibodies, and lupus anticoagulant were measured before plasmapheresis and one day after treatment.

MEASUREMENT OF LUPUS ANTICOAGULANT, APTT, ANTICARDIOLIPIN ANTIBODIES, AND ANTIBODIES TO DNA

The APTT was assessed in our laboratory. Automated APTT reagent ${ }^{10}$ (General Diagnostics, Morris Plains, NJ, USA) which contained rabbit brain cephalin and colloidal silica was used, and all assays were performed on a CoagA-Mate/Single Channel (General Diagnostics). The normal range for APTT is $26-40$ seconds (mean (2SD)). The sample containing lupus anticoagulant showed a prolonged APTT, which was not corrected by adding normal plasma.

Anticardiolipin antibodies were measured by enzyme linked immunosorbent assay (ELISA) as described. ${ }^{11}$ The results were expressed as units, each unit equivalent to one standard deviation above the mean of results for 100 serum samples from apparently healthy blood 


\begin{tabular}{l} 
Date 1989/ \\
\hline Gestational week
\end{tabular}

Figure 1 Clinical course. Immunoadsorbent plasmapheresis was performed 25 times from the 18th to 34th week of gestation. The average dose of prednisolone was $13.95 \mathrm{mg} /$ day. ${ }^{*}$ Data expressed as prolonged APTT(s): the APTT of a control plasma was subtracted from the APTT of the patient plasma. APTT=activated partial thromboplastin time; LAC=lupus anticoagulant; $P S L=$ prednisolone; $A S P=$ aspirin; $P P=$ plasmapheresis.

donors. Lupus anticoagulant was determined by the kaolin clotting test as described by Exner et al. ${ }^{12}$ The results were assessed from the mixing curve. The sample was assessed as positive $(+)$ only if the mixing curve showed either type 1-3 pattern and negative (-) for type 4 pattern. Samples which did not match the four types of pattern of the mixing curve were assessed as $( \pm)$.

Antibodies to DNA were measured by radio-
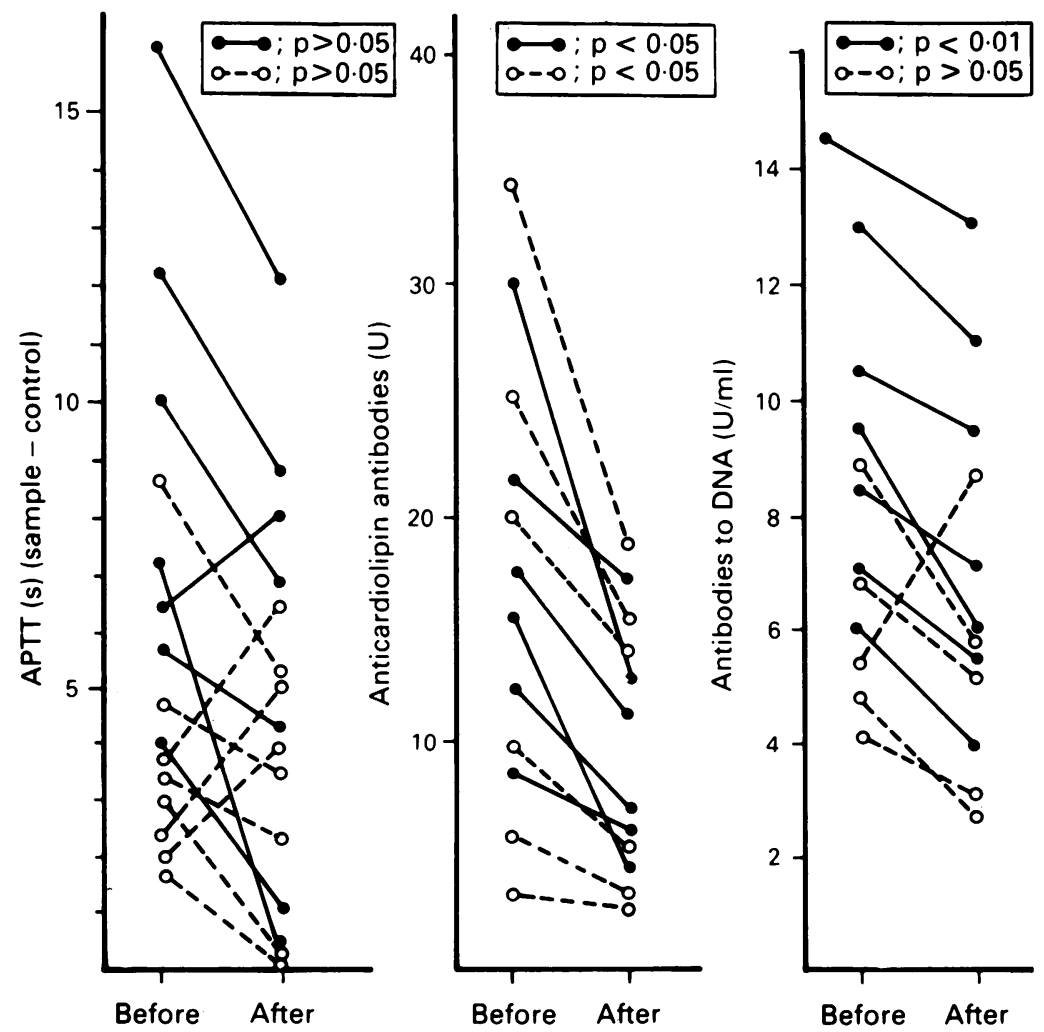

Figure 2 The activated partial thromboplastin time (APTT), anticardiolipin antibodies, and antibodies to DNA before and one day after plasmapheresis. (O) indicates the data while the prednisolone dose was $5 \mathrm{mg} /$ day; $(\mathrm{O})$ indicates the data when the prednisolone dose was increased to $30 \mathrm{mg} / \mathrm{day}$. immunoassay. The normal value was less than $10 \mathrm{U} / \mathrm{ml}$.

\section{Case report}

A 34 year old woman was referred to our hospital during the 18th week of her fourth pregnancy. She had systemic lupus erythematosus, which had been diagnosed in 1976. Since 1978 she had been taking 5-10 mg prednisolone daily and had not had any serious illness or disorders except for three previous spontaneous abortions, which all occurred between the 16th and 24th week of gestation and had been treated with prednisolone at a maximum dose of $40 \mathrm{mg} /$ day during pregnancy. Results of physical examination, routine biochemistry, and urine analysis were normal. Her erythrocyte sedimentation rate was $72 \mathrm{~mm} / \mathrm{h}$, antinuclear factor was positive (1/1280), and antibodies to DNA were $18.5 \mathrm{U} / \mathrm{ml}$ (normal $<10.0 \mathrm{U} / \mathrm{ml})$. Antibodies to SSA and SSB were negative. Serum immunoglobulin and complement concentrations were normal. Coagulation studies showed a normal prothrombin time with a prolonged APTT of $43.7 \mathrm{~s}$ (normal $30.6 \mathrm{~s}$ ). Lupus anticoagulant was detected by a prolonged kaolin clotting time, which was not corrected with normal plasma. Platelet count was slightly decreased $\left(110 \times 10^{9} / 1\right)$. Serum anticardiolipin antibodies (IgG) were detected at the level of 20.5 units. A serological test for syphilis was negative.

Treatment two to three times a week with adsorbent plasmapheresis using a dextran sulphate column was started during the 18th week of gestation in addition to low dose prednisolone $(5 \mathrm{mg} /$ day $)$ and $80 \mathrm{mg} /$ day of aspirin (fig 1). Activated partial thromboplastin time, antibodies to DNA, anticardiolipin antibodies, and lupus anticoagulant were measured before plasmapheresis and one day after treatment. As indicated in fig 2 the prolonged APTT, levels of anticardiolipin antibodies and antibodies to DNA improved with immuno- 
adsorbent plasmapheresis. During the 23rd week of gestation increases in the prolonged APTT and anticardiolipin antibodies were noted again. Although signs of abortion, placental insufficiency, and retardation of fetal growth were not detected, prednisolone was increased to $30 \mathrm{mg} /$ day as the patient had already had three previous abortions. Laboratory examinations showed normalisation of the APTT, anticardiolipin antibodies and the lupus anticoagulant became negative, and prednisolone was tapered to $12.5 \mathrm{mg} /$ day. During the 34th week of gestation, retardation of fetal growth rate, and oligohydramnios were noted by echography. Therefore, caesarean section was undertaken and a baby girl (1600 g; small for date: Apgar score 8) was delivered. The placenta showed focal and decidual infarctions. Both mother and daughter progressed well after birth. The baby gained weight and was completely well at the age of one year. During the course of pregnancy the average dose of prednisolone was $13.95 \mathrm{mg} /$ day and immunoadsorbent plasmapheresis was performed 25 times between the 18th and 34th week of gestation.

\section{Discussion}

Plasmapheresis during pregnancy has been reported for the treatment of rhesus isoimmunisation ${ }^{13}$ and fetal heart block in patients with connective tissue diseases. ${ }^{14}$ Maternal antibodies or factors which may cause serious complications to the fetus were removed by plasmapheresis and serious side effects were not reported.

Adsorbent plasmapheresis is now used for the treatment of familial hyperlipidaemia, ${ }^{15}$ rheumatoid arthritis, ${ }^{16}$ and systemic lupus erythematosus ${ }^{7}$ with dextran sulphate or hydrophobic amino acid columns. We recently found that antibodies to DNA and anticardiolipin antibodies were selectively removed by a dextran sulphate column compared with columns of other ligands and that a reduction of about $40-50 \%$ in the titres of antibodies to DNA and anticardiolipin antibodies was obtained by 2 litre plasmapheresis. ${ }^{8}$ Therefore, this patient was prophylactically treated with adsorbent plasmapheresis and the dose of prednisolone was kept at $5 \mathrm{mg} /$ day at the start of treatment. The APTT, antibodies to DNA, and anticardiolipin antibodies showed gradual improvement until the 23rd week of gestation. Plasma APTT, anticardiolipin antibodies, and antibodies to DNA were decreased by immunoadsorbent plasmapheresis (fig 2). Although the levels of antibodies to DNA and anticardiolipin antibodies while the prednisolone dose was $5 \mathrm{mg} /$ day were significantly decreased by plasmapheresis $(\mathbf{p}<0.01, p<0.05$ respectively) the APTT did not show significant change by Mann-Whitney analysis $(\mathrm{p}>0.08)$.

As the prednisolone dose was increased during the 24th week of gestation and the fetal growth retardation and oligohydramnios occurred at the 34th week, however, adsorbent plasmapheresis may not be a potent treatment for patients with the lupus anticoagulant syndrome. The possibility must be considered that not only is the removal of lupus anticoagulant and anticardiolipin antibodies required but also production of these antibodies must be suppressed by treatment with medium or high doses of prednisolone.

There are two reasons why we consider that the immunoadsorbent plasmapheresis had a favourable effect in preventing abortion. Firstly, the patient was able to maintain her pregnancy until the end of the 23rd week of gestation with prednisolone as low as $5 \mathrm{mg} /$ day, though she had had three previous abortions between 16 and 24 weeks gestation while receiving $20-40 \mathrm{mg} /$ day prednisolone. It has been reported that up to $68 \%$ of fetal deaths occur during 0-20 weeks of gestation in patients with systemic lupus erythematosus who have lupus anticoagulant and anticardiolipin antibodies. ${ }^{17}$ Secondly, despite the focal and decidual infarctions of the placenta she was able to continue her pregnancy with relatively low doses of prednisolone (average $13.95 \mathrm{mg} / \mathrm{day}$ ).

In conclusion, immunoadsorbent plasmapheresis using dextran sulphate was considered to be a useful prophylactic treatment for reducing the risk of recurrent spontaneous abortion in patients with the antiphospholipid syndrome. It is a possible alternative treatment, especially for patients whose condition cannot be controlled with high dose prednisolone or immunosuppressant drugs, or both, or for those who have adverse reactions to steroid treatment.

1 Branch D W, Scott J R, Kochenour N K, Hershgold E. Obstetric complications associated with the lupus anticoagulant. N Engl f Med 1985; 313: 1322-6.

2 Feinstein D I. Lupus anticoagulant, thrombosis and fetal loss. NEngl F Med 1985; 313: 1348-50.

3 De Wolf F, Carreras, L O, Moerman P, Vermylen J, van Assche A, Renaer M. Decidual vasculopathy and extensive placental infarction in a patient with repeated thromboembolic accidents, recurrent fetal loss, and a lupus anticoagulant. Am f Obstet Gynecol 1982; 142: 829-34.

4 Byron M A. The clotting defect in SLE. Clin Rheum Dis 1982;8: 137-51.

5 Carreras L O, Vermylen J, Spitz B, Van Assche A. "Lupus" anti-coagulant and inhibition of prostacyclin formation in patients with repeated abortion, intrauterine growth patients with repeated abortion, intrauterine growth retardation and

6 Lubbe W F, Butler W S, Palmer S J, Liggins G C. Fetal survival after prednisolone suppression of maternal lupus anticoagulant. Lancet 1983; i: 1361-3.

7 Kinoshita M, Aotsuka S, Funahashi T, Tani N, Yokohari R. Selective removal of anti-double-stranded DNA antibodies by immunoadsorption with dextran sulphate in a patient with systemic lupus erythematosus. Ann Rheum Dis 1989; w8: $856-60$.

8 Tsuda H, Taniguchi $\mathrm{O}$, Mokuno $\mathrm{C}$, et al. Utilization of dextran sulfate column plasmapheresis to remove anticardiolipin antibodies. Fapanese fournal of Artificial Organs 1989; 18: 7-10 (in Japanese).

9 Hitomi Y, Ikari N, Fujii S. Inhibitory effect of a new synthetic protease inhibitor (FUT-175) on the coagulation system. protease inhibitor (Fostasis 1985; 15: 164-8.

10 Babson A L, Babson S R. Comparative evaluation of a partial thromboplastin reagent containing a non-setting, particulate activator. Am f Clin Pathol 1974;59: 856-60.

11 Harris E N, Gharavi A E, Patel S P, et al. Evaluation of the anticardiolipin antibody test: report of an international Workshop held on 4th April 1986. Clin Exp Immunol 1987; 68: 215-22.

12 Exner T A, Rickard K A, Kronenberg H. A sensitive test demonstrating lupus anticoagulant and its behavioural demonstrating lupus anticoagulant and
patterns. Brf Haematol 1978 ; $40: 143-51$.

13 Fraser I D, Bothamley J E, Bennett M O, et al. Intensive antenatal plasmapheresis in severe rhesus isoimmunization. Lancet 1976; i: 6-8.

14 Buyon J, Roubey R, Swersky S, et al. Complete congenital heart block: risk of occurrence and therapeutic approach to prevention. F R heumatol 1988; 15: 1104-8.

15 Nakajima T, Nakamura T, Funahashi $T$, et al. A novel system of $\mathrm{LDL}$ apheresis combining a centrifugal plasma separator with a specific $\mathrm{LDL}$ adsorption column. Atheroseparator with a specific
sclerosis 1988; 73: 143-8.

16 Takahashi K, Yoshinoya S, Yoshizawa H, Miyamoto T. Extracorporeal hydrophobic amino acid adsorbent therapy in rheumatoid arthritis. Clin Rhewmatol 1987; 6: 553-63.

17 Lubbe W F, Liggins G C. Lupus anticoagulant and pregnancy. Am f Obstet Gymecol 1985; 153: 322-7. 